\title{
The emergence of a multi-scalar growth regime and scalar tension: The politics of urban development in Songdo New City, South Korea
}

\author{
HaeRan Shin * \\ Sehoon Park ${ }^{* *}$ \\ Jung Won Sonn ${ }^{* * * \wedge}$ \\ * Department of Geography, Seoul National University \\ ** Korean Research Institute of Human Settlement \\ **** Bartlett School of Planning, University College Lonodn \\ ^Corresponding author, email: j.sonn@ucl.ac.uk
}

\begin{abstract}
This study approaches the politics of urban development from within the framework of the emergence of a new multi-scalar growth regime and the path-dependence of the Korean developmental state. Through a case study of the Songdo New City development in South Korea, this study looks at how the scalar division of labor among various actors has interacted with the emergence of a multi-scalar growth regime. We focus on the logic by which different scales of governmental and non-governmental actors cooperate and, at the same time, compete with one another for authority over economic development. Our findings demonstrate, first, that the new regime resulted from the emergence of downward staterescaling to the local scale and of private business as a key actor. Second, the regime actors have been involved in scalar tensions and have constantly negotiated the scalar divisions of labor among them. This research provides a contextualized example of a spatio-temporal logic in which statehood has been transformed into a network.
\end{abstract}

KEY WORDS: growth regime, the politics of urban development, rescaling, Songdo New City, scalar tension

\section{Introduction}

This paper analyses the politics of urban development of the Songdo New City in South Korea under the lens of regime theory, ${ }^{1}$ teasing out the complex and evolving

\footnotetext{
${ }^{1}$ All of the regimes we talk about are various kinds of 'growth' regimes, where an earlier, post-war state-led developmentalist regime existed that has been supplanted by a more multi-scalar-oriented growth regime. Growth regimes are one of several different urban regime types. A typology by Stone $(1998,1993)$ includes maintenance regimes, development regimes, middle class progressive regimes, and regimes devoted to lower-
} 
architecture of a growth regime. It focuses on the rearrangement of scalar ${ }^{2}$ divisions of labor among multi-scalar actors of a regime-in-operation. The Korean politics of urban development has witnessed the emergence of a new regime and the continuing pathdependence of the Korean developmental state. ${ }^{3}$ The Incheon city government initiated the Songdo International City, located 65 kilometers west of Seoul; later in 2003, the nation state designated it a part of the Incheon Free Economic Zone ${ }^{4}$ (Kim, 2006). Through an analysis of the process of the implementation of the Songdo development over time (1986 to 2010), ${ }^{5}$ this paper analyses how new multi-scalar actors (i.e., the Incheon city government, international developers, and civic organizations in addition to the nation state) come to form a growth regime and how scalar tensions arise within the dynamics of collaboration and competition.

As its legacy as a developmental state implies, the Korean state has initiated, controlled, and managed urban development by hiring and collaborating with domestic private developers. In the context of the development of new towns and Free Economic Zones, ${ }^{6}$ the nation state has been the predominant leader within the country thus far. Therefore, the analytical framework of the growth regime (Stone, 1989) is helpful only in a comparative sense in noting the differences between the western context and that of Korea and other Asian countries.

In the case of the Songdo development, however, we noticed the birth of a growth regime especially instrumental growth regime for project accomplishment as defined by Stoker and Mossberger (1994). The city government and international developers collaborated and competed with the nation state as key actors, and their common interests emerged as a crucial driving force of the growth regime. As the regime actors are multi-scalar, the tension and the dynamics call for a rereading of the urban growth regime and state rescaling within the Korean context.

In this paper, we attempt to answer the question: How has the arrangement of a new regime simultaneously formed and been formed by scalar divisions of labor between different actors? How has the politics of urban development interacted with the detailed scalar geography of the state? Our approach involves a slight shift in the emphasis of the argument away from the western urban growth regime, which focuses on actors' collaborations, toward urban economic growth. We, rather, focus on the logic by which different scales of governmental and non-governmental actors cooperate and, at the same time, compete with one another for authority over economic development. We see the convergence (the

class opportunity expansion. Development regimes are concerned with changing land use to promote growth. ${ }^{2}$ Scale in this study refers to the range of social arrangement of and interactions between levels of organization. Scales are both materially and socially constructed (Reed \& Bruyneel, 2010). As Brenner (2009) points out, rescaling is distinguished from other elements of state restructuring, including networking, by involving the function of spatial strategies.

${ }^{3}$ The concept of the developmental state has been controversial. In this study, it is comprehensively defined as a nation state that has led by pursuing economic growth as a top priority. East Asian states including Japan, South Korea, and China are representative examples.

${ }^{4}$ In addition to Songdo, the Korean government has designated five other areas nationwide as Free Economic Zones. The Korean nation state designed and implemented the Free Economic Zone policy after the Asian financial crisis of 1997-1998. The nation state's aim was to create new growth engines within the service sector similar to the free economic zones of Shanghai and Dubai.

${ }^{5}$ This study is based on the results of a collaborative research project on new town developments in South Korea that has been entirely funded by the Korean Research Institute for Human Settlement. Geographically, Songdo belongs to the city of Incheon.

${ }^{6}$ The development of new towns and the development of Free Economic Zones (FEZs) are different from one another. Free Economic Zones have exceptional deregulation and tax benefits that new towns do not. Songdo New City has been defined as both, at different times, first as a new city and then as a Free Economic Zone. Songdo was initially considered as a candidate for a new town; then, in 2003, it was selected to be a Free Economic Zone. 
emergence of the new growth regime) and the divergence (the path dependence of the nation state's dominance and ideology) between the growth regime in the western contexts and the Songdo case. By looking at the dialectic interaction between path dependence and a new form of network, this research contributes to growth regime theory by highlighting the formation of growth regimes in non-Western countries, where the state has historically played a predominant role in economic policy. Through an actor-centered approach generated from archival analysis and in-depth interviews, our findings demonstrate how growth-oriented Korean statehood has given way to a new multi-scalar growth regime and how devolution has influenced the spatial strategies of the regime's actors.

To conduct these analyses, we organize the rest of this paper as follows. In the first section, we discuss the theoretical framework through a rereading of the regime theory literature in the context of the developmental state. Next, we briefly introduce our research method and the background of the case. In terms of empirical findings, we first examine how the multi-scalar growth regime formed and what relations key actors had with others in the rearrangement of the scalar division of labor. Second, we address the scalar tension between the urban government and the nation state regarding the Incheon Free Economic Zone Authority. The last findings section investigates who plays the role of coordinator in the context of the politics of the new growth regime. We seek out the academic and policy implications of the findings in the concluding discussion.

\section{Urban growth regime in the developmental state}

The politics of urban development in South Korea has been distant from the regime approach as a result of a lack of partnership and of direction on the part of private business in the Korean context. In recent years, some studies (Bae and Sellers, 2007, for example) have noted changes that have made the Korean context more akin to western ones. Regime theory (Stone, 1989) has been predominant in the literature on the politics of urban development for decades in western societies (Mossberger and Stoker, 2001). The concepts of the urban regime include a perspective informed by political economy that "rejects both pluralist assumptions that governmental authority is adequate to make and carry out policies, as well as structuralist assumptions that economic forces determine policy." (Mossberger and Stoker, 2001: 812). Power as part of these concepts refers to the political power to act and to achieve an outcome rather than to power over others.

Regime theory has focused on the collaboration between governmental actors and non-governmental actors (businesses in particular) where property development-led urban growth has been a common interest between these actors. ${ }^{7}$ A regime is an informal yet relatively stable coalition that provides other actors access to institutional resources. The combined group of government and private actors establish authority over the populace, which governmental actors provide, and over national economic resources, which private actors give. Regime theory puts forth exchange politics, the arrangement of such exchanges of the access to political and economic resources, as a main condition of regime politics.

The entrepreneurial local government ${ }^{8}$ accommodates local businesses' pursuit of profit (exchange value) via real estate development (Harding, 1995), as it is interested in financial benefits as well as the political advantages that an urban development project can create (Stoker and Mossberger, 1994). To attract mobile capital, new residents, and tourists, the local government has pursued a type of urban growth that improves upon the landscape

\footnotetext{
${ }^{7}$ Urban growth machine theory (Molotch, 1976; Logan and Molotch, 1987) has also focused on the same theme.

${ }^{8}$ Peterson (1987) has demonstrated how the local government pursued developmental policy rather than redistributional policy in order to maintain compatibility with business interests.
} 
and infrastructure. A main consequence of the existence of an urban growth regime is a conflict between use values that local residents pursue and the exchange value that economic and property development are interested in (Logan and Molotch, 1987). The regime approach pays special attention to how the structure of society and existing power relations privilege particular actors in the pursuit of certain interests within a coalition (Blanco, 2013; Stoker and Mossberger, 1994).

In the case of the city of Atlanta, regime politics has demonstrated three characteristics. First, non-governmental actors not only control most investment activities, but also manage most social-associational life. A number of previous studies have emphasized the importance of businesses for economic development and local growth, although the involvement of businesses is not necessarily a dominant one (Stone, 1987; Mossberger and Stoker, 2001). These same studies have shown that the role of the government shifted from commanding action to inducing action. Second, the emergence of a growth regime formation is a process of social-coproduction. The appropriate form of growth regimes depends on the context within which they are established, including what are considered the main urban problems faced by an urban environment.

Regime theory has been contested on the basis of whether it is also a useful approach in the context of Western countries. While Imbroscio (2003) has criticized conceptualizing growth regime theory in a rigid and static manner, Davies (2003) has considered concept stretching, arguing that regime theory is not an appropriate approach for the analysis of urban coalitions in the context of Davies' study of the UK. Stone (2004), however, refused to focus on whether a given locality or set of localities pass a litmus test to qualify as a growth regime. Rather, he focused on how governing arrangements take shape and what motivates key actors to pursue an agenda.

The politics of urban development in the Korean context has involved the dominance of the nation state and a hierarchy between the government and businesses. Especially for new town development and mega-city projects, the nation state has controlled hiring or strongly intervened in the activities of businesses (Grange and Jung, 2004; Kim and Kim, 2000). Based in part on the weakness of the private sector and working classes in the processes of industrialization and urbanization, the state enacted the Land Expropriation Act in 1962. The act enabled the state to access or take over land for its industrial and urban development projects by expropriating land for both industrial development and commercial residential development. National economic growth has been a powerful ideology in South Korea for decades, ever since the end of World War II and the division of Korea into North and South during and after the Korean War. The hostile division between South and North Korea motivated and strengthened discourses of national competitiveness. The discourse of globalization has further promoted the ideology of national competitiveness.

Because of its characteristics during the state-led industrialization periods of the 1960s and 1970s, some scholars have examined the politics of urban development in South Korea from within the framework of the developmental state. (Park, 1998; 2003; Sonn, 2007; Kong, 2000; Saito, 2003; Bae and Sellers, 2007) ${ }^{9}$ The characteristics of a developmental state include a blurred boundary between public and private sectors, a focus on nationalistic collective interest, economic development as a primary logic of legitimacy, strong planrationality, and an autonomous, technocratic system (Saito, 2003: 289-290; Tsukamoto, 2012). A developmental state receives public support for spatial strategies based on national competitiveness (Harvey, 2005). Developmental state theory, however, is controversial, and

\footnotetext{
${ }^{9}$ It is beyond the scope of this study to clarify if the developmental state theory is flawed and if South Korean state is still one. We note that South Korea has had a developmental state legacy because the nation state has been relatively dominant in urban development.
} 
some criticize it for having an overly simplified view of a state-autonomous system (Chang, 2003).

Nonetheless, there can be little doubt that the political economy of postwar South Korea was in fact at least state-led. Interventions in market mechanisms have been highly selective, and the state has worked with and often promoted markets rather than exercise direct control (Önis, 1991). However, since the 1990s, there have been some significant changes in the operation of the state mainly because of internationalization of business activities and labor movements (Minns, 2001). The changes reduced control over the domestic market (Pempel, 1999) and produced a shift to knowledge, service, and high-tech oriented sectors (Hahm and Plein, 1995; Chung and Kirby, 2002). This suggests that new leadership and new partnerships will emerge as part of developments that are more decentralized, partnership-based, and internationalized.

In the Korean context, the transition from the highly centralized developmental state to partially decentralized urban development policies took place simultaneously with transition for explicit control of urban development by the nation state to the embedded dominance of the nation state. (Park, 2008; Sonn, 2010) Urban entrepreneurialism (Harvey, 1989) emerged in 1994, at the same time as direct elections for local governments began. A number of local governments started the growth-oriented place marketing strategies reflected in urban development projects. A legacy of the developmental state, however, remains embedded in the political economic structure (Moon and Prasad, 1994).

The Songdo New City case demonstrates the general applicability of growth regime theory. It is not necessarily a long-term stable regime but an instrumental growth regime that leads to project realization. The "project realization" occurs under instrumental regimes, short-term and project oriented, and achieving a tangible result within these time spans is usually critical (Stoker and Mossberger, 1994). Completing specific projects is the common purpose shared in such regimes, and it is an incentive for members to cooperate (1993: 201). The instrumental regime for project realization is identical to the development regime defined by Stone (1998).

Public-private partnership (Davies, 2003) and regime are sometimes used interchangeably (Stoker and Mossberger (1994) and Strange (1993), for example). Strange (1993) saw public-private partnership as a process toward developing a regime and suggested that the partnership that he studied exhibited tendencies of a symbolic revitalizing regime (1993: 371). More distinctively than that, public-private partnerships can be defined in terms of "an ideological commitment to collaboration within local authorities" (Davies, 2003: 253) as the local authorities consider market-led growth not only positive but also necessary. Public-private partnerships are also bureaucratic structures operating under strong central government control.

According to these criteria, the Songdo case fits the framework of the growth regime rather than the public-private partnership because key actors have financial interdependence (Davies, 2003). They also involve collaboration based on the need to combine resources for the power to accomplish tasks beyond a symbolic cooperation (Mossberger and Stoker, 2001). The regime is an autonomous institution involving shared governing outcomes, not controlled by a central government (Davies, 2003). A public-private partnership can be a process toward a regime. This paper focuses on the beginning of a growth regime and does not exclude the fact that a part of the process is public-private partnerships.

Despite their useful explanatory power, conventional theories of the urban growth regime have room for revision in terms of providing a theoretical framework useful for the Songdo case. We propose the construct of a "multi-scalar growth regime" to address some of the gaps. First, the main actors of cooperation and coalition add the central government and 
international private actors (in this case, consisting of a single international company) to the typical main dynamics between the urban growth regime, local government, and local private businesses. The central government provides authority based on its dominant power and its reputation as predominant from its past status as a state-led regime, while the international private company provides financial resources. In addition, the politics of the multi-scalar growth regime demonstrates different dynamics from that of a standard growth regime.

\section{Scalar tension among multi-scalar actors of the regime}

Despite their common interests surrounding urban growth, the labor division among multi-scalar actors is not stable, as each one goes through new dynamics as a project proceeds. As the roles of governmental actors and that of non-governmental (usually businesses) actors usually differ from one another, a coalition made up of these actors is likely to be based on conflict rather than natural cooperation. As Mossberger and Stoker (2001) have pointed out, the concept of regime transformation has not been well theorized. We suggest the notion of cooperative conflict (Sen, 1990), in which participants have a congruent collective interest and are obliged to cooperate despite conflicting interests. It is important to discern not only motivations held in common between different actors that lend themselves to cooperation and coalition building for governing cities but also the tensions between such actors.

Under the previous, state-led development regime in Korea, the scalar labor division was quite centralized. As the growth regime involved actors from various geographic scales (urban, national, and global), tensions as well as cooperation among the multi-scalar actors of the new regime was a key feature of the regime (Bae and Sellers, 2007). ${ }^{10}$ The new regime is likely to have a multi-scalar labor division that continues to include the traditionally predominant actor, the nation state, with international businesses newly involved, and with local government emerging as a new leader as well. Some of the previous roles of the nation state are thus transferred to other actors.

Scholars of state rescaling have focused on the transformation of the nation state's functions and power. The private sector has increased its influence by capturing regulatory agencies through personal networks, bribery, political pressure, and the provision of partial information (Bernstein, 1955; Laffont \& Tirole, 1991; Levine \& Forrence, 1990; Stigler, 1971). ${ }^{11}$ The voluntary sector has also emerged as an influential actor that participates in the decision-making and negotiation process. However, the continued active role of the nation state (e.g., Jessop, 2002; Brenner, 2004; Goodwin, Jones, and Jones, 2005; Jones, 2001; MacLeod, 2001) has continued to receive attention. These studies see a hollowing-out process consisting of selective withdrawal on the part of the state rather than its exclusion from local affairs. This selective withdrawal can be part of a strategy for a new form of leadership. Authors such as Jessop $(1994,2002)$ and Brenner (2004) demonstrate that the relocation of power from the national to the regional or local scale represents a reconfiguration of state power rather than a weakening of the nation state (See also Jones, Goodwin, \& Jones, 2005; Allen \& Cochrane, 2007; Fujita, Forthcoming; MacLeod \& Jones, 2007; Park, B-G 2008 for similar views.).

State rescaling from the view of regime theory (Bulkeley, 2005; MacLeod \& Goodwin, 1999; MacLeod \& Jones, 1999; Peck \& Tickell, 1992; Jonas \& Ward, 2007) effectively demonstrates the dynamics of scalar practices. The rescaling in multi-scalar regimes is constituted not only by rescaling upward (from the local to the global, for example) and

\footnotetext{
${ }^{10}$ Base and Sellers (2007) expressed what we refer to as "different scales" as "different levels."

${ }^{11}$ In a similar vein, political scientists have used the concept of the "iron triangle" to describe how, in the private sector, bureaucrats in related areas and national congress members in related commissions share interests (Cater, 1964; Freeman, 1965; Gais, Peterson, \& Walker, 1984; McConnell, 1966; McCool, 1990).
} 
downward (from the global to the local, for example) but also by rescaling outward and backward (to embrace historical and contextual approaches) (Reed and Bruyneel, 2010). Rescaling "inward" (within the nation state) also takes place as different interests and competition develop within the nation state. Within the seemingly coherent boundary of any organization (including the state), there are actually individuals and groups of individuals whose interests do not necessarily coincide with that of the whole organization (Powell, 1990).

The state is a set of networks ${ }^{12}$ instead of as a cohesive unit with a singular agenda, and intra-state conflicts originate from the diverse interests that exist within the state. The literature on bureaucratic politics shows that bureaucrats are likely to have an individual agenda, which often contrasts with that of the state (Allison and Halperin, 1972; Carpenter, 2010). Niskanen (1974) and Bendor and Moe (1985) show that the main agenda of bureaucrats is likely to feature a bigger budget, more personnel, and greater responsibilities, rather than serve the government's policy objectives. These heterogeneous interests and potential conflicts within the state (Cox, 1998; Mair and Cox, 1991) make state elites attempt to consolidate the individuals and groups within the state organization via various methodologies called the "state project," although such attempts are only ever partially successful (Jessop, 1990). While such differences in interests lead to conflict, they can also lead to collaboration between scales. For example, elected officials in the nation state would be motivated to take the side of local interests to get votes in the next election from local constituencies (Stratmann \& Baur, 2002).

As the dynamics of the tensions that exist between structural forces and actors' practices constitute state rescaling (Marston, 2000), power relations among actors are likewise constantly redefining, contesting, and reconstructing the dynamics (Abidin, forthcoming; Delaney \& Leitner, 1997; Silver, 2009). Scalar practices shape and, at the same time, are shaped by the structure of social interactions (Smith, 1992). The geographical scale of actors and power structures in their social relations are intertwined in the politics of scale (Swyngedouw, 1997, p. 169). Power is exercised based on existing scales but is rarely stable (Cox and Mair, 1991; Cox and Wood). This is because actors make policy, resolve conflicts, negotiate, and renegotiate at a scale that is most favorable to their interests (Jessop, 2009).

A highly centralized state can pursue economic development at an urban scale by, for instance, involving itself in urban regeneration schemes (Park, 2008). Powerful non-state actors, such as transnational corporations, can attempt to penetrate an existing scale or construct a new one. Regime actors involved influence the way that state rescaling unfolds, ${ }^{13}$ either knowingly or unknowingly. Discovering how the state is transformed in relation to and because of other actors in the process of the emergence of the new growth regime in South Korea will contribute to the literature of the politics of urban development with a focus on growth regimes and scalar division.

\section{Research Methods}

\footnotetext{
${ }^{12}$ A market and a hierarchy are extreme variants that are not likely to exist in the real world. Unlike Weber's (1968) description of a hierarchical organization, for example, those who have a higher rank cannot fully control their subordinates' actions. The distribution of power is asymmetric but never completely concentrated at the top of the organization. In that sense, a seeming hierarchy is actually a complicated web of networks featuring asymmetrical power relations. The real world market, on the other hand, is often based on transactions among a limited number of consumers and producers who care about not only immediate interests but also long-term interests, which opens the door for asymmetric power relations. (See also Granovetter, 1985.)

${ }^{13}$ In the post-war era, the national scale became stronger than it had ever been before, dominating other scales such as the supra-national or sub-national scale. However, even at that time, political actors were "jumping scales" in order to stretch their spatial influence.
} 
While our study is theoretically driven, the focus of our fieldwork lies in the grounded aspects of how this new governing regime was formed. We cross-examined various sources to elucidate the complex politics and partnerships taking shape among elite actors, complexities that are not normally visible (and remain somewhat invisible even under the sustained inquiry of our research). We conducted archival analysis, semi-structured in-depth interviews, participant observations, and site visits. We explored related archival materials, such as governmental reports, inter-organizational notes, newspaper articles, books, master plans, and meeting minutes. As a supplementary method, we selected eleven interviewees from the public sector, governmental research institutes, a local NGO, and a print media organization. The selection of the interviewees was from our investigation of reputation by asking who people involved in the project thought were key participants. Interview questions included who initiated the project, who joined later, how their divisions of division took shape, who dominated and how, and what kinds of incentives and conflicting interests different actors carried. Table 2 summarizes the characteristics of the interviews.

Table 2 about here

\section{Case Background}

Like other technologically advanced East Asian mega cities, ${ }^{14}$ the Seoul metropolitan area expanded rapidly. Throughout the period beginning with the start of rapid development in the 1960s through to the present day, the state has faced chronic housing shortages and unaffordable rises in the price of housing. The state has responded with a variety of programs, starting with the Land Readjustment Act in 1966 and the Land Readjustment projects (Grange and Jung, 2004). The state set up the Korea Land Development Corporation for the purposes of land expropriation and the Korea National Housing Corporation for the construction of public housing. These state-owned enterprises have monopolized land and housing development projects.

The housing system, and its ability to meet the housing needs of Koreans, has become a political issue. In the late 1980s, the Roh Tae Woo government (1988-1993) responded by pursuing the construction of two million housing units in five years in the capital metropolitan region and building more than ten new towns in Seoul's neighboring areas. Located within a 25-kilometer radius from the city center of Seoul, the first generation of five new towns (Bundang, Ilsan, Pyeongchon, Sanbon, and Jungdong) achieved the target of two million new housing units. ${ }^{15}$

The private sector has been increasingly involved in the housing development process, starting in the 1980s, providing new housing on a massive scale. The state and construction companies have had a close relationship as part of this increased involvement (Park, 1998; Kim and Ahn, 2002). Increasing deregulation and marketization have taken place in the aftermath of the Asian Financial Crisis. The private sector has pressured the government to deregulate planning schemes, especially the greenbelt policy, and the decrees regulating the Seoul Capital Region based on the Capital Region Management Law (Kim, 1999). The state, in the end, did deregulate the greenbelts for the construction of a second generation of new town projects.

\footnotetext{
${ }^{14}$ These are cities that have experienced substantial economic growth and urban development based on welldefined administrative and political jurisdictions. They are also characterized as statist systems of land and housing development and as involving strong national political organizations as well as extensive national land use policies (Laquian, 2005; Bae and Sellers, 2007).

${ }^{15}$ The public sector constructed $45 \%$ of these two million housing units, while the private sector supplied $55 \%$ (Chu, 2000).
} 
Compared to the prototypes of new town developments, Songdo has had a number of contrasting features, although these have changed over time. The Incheon city government initiated the reclamation of wetlands in order to develop an international new city in the 1980s. At that time, Incheon city was afflicted with an outdated industrial structure and was seeking a new model of development to distance itself from its traditional reliance on the manufacturing industry. The Incheon city government concluded a memorandum of understanding (MOU) that went into effect later in 2001. This MOU was made with Gale \& Wentworth Company, a US firm that specializes in real estate development. With such support, the city government persuaded the nation state to provide legal and financial support. In terms of the institutional structures of Free Economic Zones, there is an Incheon Free Economic Zone Authority at the local (city) scale. There is also a Free Economic Zone Planning Office of the Ministry of the Knowledge Economy at the national scale and, at the regional scale, a regional Free Economic Zone headquarters in each region with a Free Economic Zone (Kim, 2006).

The Incheon Free Economic Zone covers a total area of 209 square kilometers, 51,755 acres (representing a third of the geographic area of Seoul), and is comprised of the Songdo, Cheongna, and Yeongjong districts. The Incheon Free Economic Zone is to be home, once it is complete, to a planned population of 480,000, and the Incheon city government anticipates spending approximately $\$ 15$ billion toward building up infrastructure during the implementation period of the Zone, spanning 2003 to 2020 (Incheon City Government and Ministries of the Knowledge Economy, 2007). Figure 1 shows the location of Songdo as well as details of Songdo International City, as well as the developmental plan for the Incheon Free Economic Zone.

Figure 1 about here

There were several unique factors to the Songdo development project." First, it targeted the enhancement of regional and national competitiveness by attracting foreign direct investment. Second, it is a product of complicated interactions between the national and city governments. Third, an international private investor, Gale \& Wentworth Company, a US firm, something that had previously been unheard of in Korea's planning history, was also involved as a key actor (Kim \& Ahn, 2006).

\section{The formation of the multi-scalar growth regime of the Songdo development}

Insight into regime systems can derive from looking over longer timeframes (Reed and Bruyneel, 2010). Over the past twenty-four years, between 1986 and 2010, the partnership among actors has become increasingly complicated.

\section{Table 1 about here}

Table 1 indicates the emergence of the urban growth regime and the changes in the makeup of the Songdo development's key actors over time. As the number of actors and their different interests increases, the importance of partnership increases dramatically as well. The formation of the multi-scalar growth regime of the Songdo development took place in the following ways, as emerged from an analysis of our interviews. ${ }^{16}$ The Songdo growth regime

\footnotetext{
${ }^{16}$ For a better understanding of the major events that took place during development, please see the timeline in Appendix 1, which summarizes them.
} 
demonstrates financial interdependence and autonomy in the institutional setting along with features of an instrumental growth regime.

First, the emergence of the Incheon city government as an active actor was noticeable in terms of downward state rescaling. In the late 1980s, some local officials took the initiative, devising an entrepreneurial vision to transform Incheon into an international city by using the airport and reclaiming land (Park, 2008). The biggest barrier was the Capital Region Management Law, enacted in 1984 (Lee \& Shin, 2012, p. 1338), which controlled the urban growth of Seoul, Incheon, and the surrounding Gyeonggi province. To receive the exceptional approval of the nation state to build outside of the restrictions of this law, those who wanted to start new developments contacted the president of Korea at the time, Chun Doo-hwan (1980-1988), directly. Because of growth regulation, it took fifteen years (1986-2001) to receive approval to reclaim the land for the purposes of the new Songdo development.

For a while after approval, the city staff seemed to avoid a tight-knit connection to the nation state. It should be noted, though, that there were different opinions within the Incheon city government at any given time, and different mayors of the city over time had different directions they wanted to pursue. Mayor Ahn Sang Soo (2002-2010), from the conservative Hannara Party, led the development of Songdo and was consistently enthusiastic about it. The next mayor, Song Yeong Gil (2010-2014), representing the Democratic Party, was critical about the development and increasing inequality between Songdo and the old city center of Incheon. He said that the business district had decreased by 38 percent, such that the Incheon Free Economic Zone had become a bedroom community (Hankook Kyungje, June 4, 2010).

Second, the most notable characteristic of the exchange politics of the new regime was international private developers' participation. As the sole actor, the city government focused on attracting international investment and constructing residential buildings (Incheon Ilbo, January 15, 2001; Lee, 2005). The private developers represented 39 out of 46 trillion won invested between 2003 and 2009, while the public sector invested the remaining 7 trillion won. A report written by the Incheon Free Economic Zone Authority (2010) stated that the Incheon Free Economic Zone development would not be possible without collaboration with private developers. ${ }^{17}$ Governmental actors had access to financial resources and focused on inducing action instead of commanding action. In return, the international developers expected partial authority over planning and profits from development. Such exchange politics was critical in the formation of the growth regime. Expanding to non-governmental international actors demonstrated the nature and presence of tendencies toward outward state rescaling (Reed and Bruyneel, 2010) and the formation of the regime.

New Songdo International City Development LLC (NSIC) ${ }^{18}$ comprises Gale International, a managing partner, and The Pohang Iron and Steel Company (POSCO), which is a domestic Korean company. NSIC made a contract to purchase the land, revise the land use plan, obtain approval from the nation state, and implement property development. NSIC constructed a park, a golf course, an art center, a convention center, a trade tower, and a hotel, focusing on overall quality of life to attract businesses. ${ }^{19}$ NSIC also contributed to boosting Songdo's reputation by putting it in the spotlight.

\footnotetext{
${ }^{17}$ An Incheon Free Economic Zone Authority journal (2010) emphasizes that the development does not come from citizens' tax but from land selling $(7 \%)$, the nation state $(5 \%)$, and from private developers $(88 \%)$. 18 "NSIC is a joint venture company established in March 2002 by The Gale Company LLC (a.k.a. Gale International) and POSCO Engineering \& Construction Co., Ltd. for the purpose of developing the International Business District in Songdo International City" (NSIC website http://www.songdoulife.com/English/what/partners.html. visited on June 7, 2011).

${ }^{19}$ Interviewees 5, 6, and 7, all members of the Free Economic Zone Authority, argued that if it had been the Korean Land and Housing Corporation that had been in charge during previous new town developments, they
} 
The emergence of the local government and that of international developers and increasing partnership developed the process toward the formation of a growth regime. It should be noted, however, those changes brought about new tension so cooperative conflict relations developed. The tension emerged surrounding the growth regulation of Songdo between the city government and the national Ministry of the Knowledge Economy. The city government was supportive of less regulation on the development by NSIC because the development would bring public facilities to Songdo. The nation state's ${ }^{20}$ approach depended on what role the nation state thought Songdo played in national development. Because the Incheon Free Economic Zone was subject to the new apartment price ceiling system ${ }^{21}$ as well as capital region regulations, NSIC asked for deregulation for the Incheon Free Economic Zone in order to proceed more quickly (Dong-A Newspaper, April 6, 2010). The interview with NSIC, including Stan Gale, the chair (Dong-A Newspaper, April 6, 2010), showed a strongly critical tone toward the higher Corporation Tax (22\%) than Hong Kong (17\%) and Singapore (18\%) and regulations on the activities of private businesses in South Korea. The developer also criticized that although it completed the construction of the Chadwick International School, it could not open the school because of regulations on foreign investment. As a result of deregulation, the percentage of domestic students increased from 10 percent to 30 percent (Asia Kyungje Newspaper, February 10, 2010). Gyeonggi province was also vocal in supporting deregulation.

Another cooperative conflict existed between the Incheon Free Economic Zone Authority and NSIC. In terms of hierarchical positions, the Incheon Free Economic Zone Authority was considered senior to NSIC (Interviewees 2 and 5). Unlike a typical relationship between a payer and a payee in Korean business culture, however, there was plenty of room for the company to drive the process in the direction it wanted (Lee, 2005), and some former staff members of the Incheon Free Economic Zone Authority were recruited by NSIC. Some interviewees (Interviewees 2, 5, and 6) assumed that their contribution to NSIC was strategically underhanded. In principle, NSIC was expected to discuss matters with the nation state only via the Incheon Free Economic Zone. Sometimes; however, NSIC wanted to negotiate directly with the nation state in a rather confidential way (Interviewee 3 ).

Third, it is also important to investigate the continued dominance and competition of the nation state (The Blue House and administrative ministries) over the regime. The nation state's power of approval has made its involvement quite influential, although it is not involved in the implementation of the project. For example, when Incheon wanted to attract Portman's investment to build the landmark of the Incheon Free Economic Zone, a 151storey twin building, the city of Incheon had to get the nation state's approval (Interviewee 3).

After the Asian Economic Crisis in 1997, the nation state became supportive of Songdo's local development because the state saw the urban development of a few selected cities as a key engine for national economic growth. The state suggested leveraging the opportunity to become a Free Economic Zone and decided on the direction and the initiative ${ }^{22}$ that the city government drafted. Then the two groups met to discuss it. Through the Board of Audit and Inspection, the nation state has assessed outcomes of the development. The

would have built only housing and a park.

${ }^{20}$ Because the city government has no right to create or change law, this communication took place between NSIC and the nation state.

${ }^{21}$ The new apartment price-ceiling system was legislated in 2005 and implemented as a tool to mediate inequity in the housing market. Growth regulations that encompassed Incheon included the new apartment price-ceiling system and the capital region regulation.

${ }^{22}$ The plan was made in a similar fashion to usual land-use plans because there was no model in the Korean context for a Free Economic Zone. 
Incheon Free Economic Zone has not been independently assigned because financial independence was not established.

Regarding financial support, interviewees' perceptions of the nation state's role varied. Over six years, spanning 2003-2009, the entire cost was 46 trillion won, among which the nation state's financial contribution was 2 trillion and the city government's 5 trillion. One interviewee (Interviewee 5) contended that the nation state's financial support was not significant. What the Incheon Free Economic Zone Authority wanted, he said, was deregulation, not financial aid, from the nation state (Incheon Free Economic Zone, 2009). ${ }^{23}$ For instance, the Incheon Free Economic Zone Authority appealed to the National Assembly to get an exemption from price controls on new apartments and the advanced sale system, which had been key tools of state regulation (Lee \& Shin, 2012; Kim \& Kim, 2000). The Incheon Free Economic Zone Authority was rather conscious of the power of the international developers who contributed financially by providing a convention center and a park. Despite local perceptions, the nation state spent half of its total Incheon Free Economic Zone budget on the Songdo development. According to another interviewee (Interviewee 11), without the nation state's financial aid, it would not have been such a fast, widely known, and large-scale reclamation.

Fourth, local civic organizations played the role of an anti-growth regime, but they did not make a big difference in the formation of the growth regime. A number of national and local civic organizations organized a civil measure committee to oppose the Free Economic Zone law in a forum in 2003 (Incheon Civil Measure Committee, 2003). They criticized the Free Economic Zone policy of the Kim Dae Jung and the Roh Moo Hyun regimes as a neoliberal, pro-capital policy exacerbating problems in terms of labor rights, environmental regulation, and public education. Later, in 2004, the Ministry of the Knowledge Economy designated Songdo as one of the six promising Free Economic Zones, which made opposition pointless as its implementation became inevitable. Civic organizations either became supportive of the development's direction or lost interest in it. Then, they grew cynical, as the nature of the development kept changing as the amount of land reclamation increased, as universities instead of businesses moved in, and as housingoriented development began. Despite their influence in the narratives of the popular media, civic organizations did not play a leading role in the development or in the decision-making, as their financial and political resources were limited.

\section{Scalar tension in the multi-scalar growth regime}

The new regime of the Songdo development was a nexus where dynamic rescaling renegotiated the boundaries of the activities of various actors. Two newly emerging actors, the local governmental actor (Incheon Free Economic Zone Authority) and the international developers (NSIC) mainly constituted the growth regime. In the early stage of the growth regime formation, the state rescaling took place both upward and downward. The later stage after the Asian Economic Crisis witnessed continuing path dependence. The nation state challenged the rescaling through the following claims: (1) The chair of the authority is influenced by the nation state; (2) the nation state attempted to take the Incheon Free Economic Zone Authority to the national scale; and (3) the nation state was empowered by the right to make Free Economic Zone selections.

\footnotetext{
${ }^{23}$ In any case, financial support from the nation state is not guaranteed; as stated in official documents, the nation state may support the project, and it may not. So, Incheon Free Economic Zone has had to struggle to gain support on a year-by-year basis (Interviewee 7).
} 
Although the power of making appointments to positions within the bureaucracy of the Free Economic Zone officially belonged to the city government, because the three former chairs had previously worked in the nation state, interviewees considered these chairs to have belonged to the nation state. Based on this trend, many believed that the nation state was appointing its own people to the Free Economic Zone chair. Compared to the Special Economic Zone authority in China, which is relatively independent from the nation state and the city government, the Incheon Free Economic Zone Authority is under the direct influence of the city government and is governed by the Ministry of the Knowledge Economy and other ministries of the nation state (Kwon, 2007).

The nation state started to grow concerned when one of the former chairs of the Incheon Free Economic Zone Authority complained that the authority should be independent and that the mayor and the city parliament represented barriers to achieving goals. At one point, the nation state wanted to appoint the director, a decision that brought about strong resistance from the city government, according to Interviewee 5. As the solution, the nation state sends a director candidate for consideration, and the city government ultimately makes the decision to appoint the director of the Incheon Free Economic Zone Authority.

Second, the nation state once tried to install a Special Purpose City government to put the Incheon Free Economic Zone Authority under nation state control (Hangyere Newspaper, July 23, 2006). This attempt to form a local agency (Bayirbağ, 2010) failed, blocked by harsh objections from the city government. This incident epitomized the complexity of the institutional environment of the Songdo project today, highlighting the shift from local initiatives and national reluctance to national dominance and local resistance. The effects of this incident and the tension continued in the aftermath, a number of interviewees said. ${ }^{24}$ The nation state is still currently interested in making the Free Economic Zone independent from the Incheon government. Because national law allows for that kind of change, the nation state is legally capable of making that decision.

Although the nation state stated its involvement was not a matter of dominance, this competition seemed to be a very sensitive issue for both the city government and the authority. Additionally, the Ministry of the Knowledge Economy initiated the Incheon Free Economic Zone system as part of the process of the Ministry's expansion (Kwon, 2007). Most of the interview subjects said that the Ministry of the Knowledge Economy had attempted to expand its influence over the Incheon Free Economic Zone.

A majority of the interviewees agreed that the actors, especially the nation state and the city government, rarely took action unless an urgent matter arose. Because there was no official communication channel between the national and the city governments, the usual modes of communication included calling on the telephone and discussing matters over a meal. These interviewees attributed the lack of communication to the nature of Korean bureaucrats, who are reluctant to take any action beyond their required responsibilities.

The tension remains ongoing, as the following statement indicates:

\footnotetext{
${ }^{24}$ A different interpretation from our interviewees was that the intention of the nation state, especially the Free Economic Zone Planning Office, was to enhance the autonomy of the Incheon Free Economic Zone Authority, not to take it over (Interviewee 10). The nation state's view was that the authority's dependency on the city government makes things more complicated. Moreover, a Free Economic Zone as a Special Purpose City government would better be able to attract foreign capital and would work for other Free Economic Zones like Pudong and Shanghai in China. A Free Economic Zone can be independent from both the local and nation states. Another interview subject said that because the Incheon Free Economic Zone Authority is located in the local (Incheon) sector, local council is also involved. Hence, development is not being implemented efficiently. He said that if the nation state were to take control of the Incheon Free Economic Zone Authority, it would be easy to gain financial support and outside trust.
} 
Communication between Incheon [government] and [the] Ministry of Knowledge Economy is rare. The Ministry of Knowledge Economy wants to take the Incheon Free Economic Zone Authority under their purview while Incheon avoids talking with them [Ministry of the Knowledge Economy], it seems. If Incheon had a financial problem, the Ministry of Knowledge Economy would be able to take over the institution while stepping in to financially support it [the Incheon Free Economic Zone Authority]. (Interviewee 2, Governmental Research Institute, April 12, 2010).

As a ministry for the national economy, the Ministry of the Knowledge Economy used to be uninvolved in spatial strategy. However, the Free Economic Zone Planning Office of the Ministry of the Knowledge Economy was responsible for changing and approving the development plans of Songdo International City. The Ministry of Land, Transport and Maritime Affairs usually led accommodations to legal and institutional frameworks for new town developments. Such a large development has in the past been funneled through the Central Urban Planning Committee for Decision-Making and Assessment, but in the case of Free Economic Zones, it has been the Free Economic Zone Committee that has played this role. This committee includes ministers and university professors, and the chair is the minister of the Ministry of the Knowledge Economy.

Inward rescaling took place as tension between the Ministry of the Knowledge Economy and the Ministry of Land, Transport and Maritime Affairs increased. Because the Free Economic Zone laws were initiated by the Ministry of the Knowledge Economy while the development process was led by the Ministry of Land, Transport and Maritime Affairs, their roles caused conflict and were henceforth redefined. The Ministry of Land, Transport and Maritime Affairs, however, ignored the legislations and made the Ministry of the Knowledge Economy go through the Central Urban Planning Committee for their development proposals to obtain approval in cases of designation and other changes. The Ministry of the Knowledge Economy also divided land for management, with each division having rather independent decision-making power over its own land.

Third, it is worth noting that the nation state's economic strategy to overcome the Asian Economic Crisis effected a power shift from a selected city, Incheon, to a selector, the nation state. The influence of the nation state, particularly in the shape of the Ministry of the Knowledge Economy, was visible when it assessed six Free Economic Zones and removed weak Free Economic Zones $\left(90.51 \mathrm{~km}^{2}\right.$ in total) from the list (Asia Economy Newspaper [Asia Kyungje], February 8, 2011). The nation state decided to focus on certain selected zones, including Songdo, as the top priority (Jung Ang Newspaper [Jung Ang Ilbo], January 26, 2011; Asia Economy Newspaper [Asia Kyungje], February 8, 2011). There was a clear recognition of the state's legal and institutional power. Regarding the importance of the state's power and role, Interviewee 10 noted,

The nation state designated six Free Economic Zones in total. Isn't [that] the influence and power of the nation state's decisions? Taxation reduction, the kind of industries to attract — these decisions all come from the national [government]. (April 23, 2010)

Such roles as a developmental state were possible in the discourse of national crises, including the postwar recovery and competition with North Korea. The national economic crisis brought about the reemergence of the nation state as an umpire in competitions among cities. Getting financial support, especially for infrastructure, became extremely competitive among the six Free Economic Zones. There was a competition among these Zones for funds so limited as to be insufficient for even one project. Local actors must therefore make an effort to confirm receipt of support for their facilities every year by contacting the national assembly and other institutions, Interviewee 7 argued. For example, the construction of the 
underground speed train that carries people from Songdo to Seoul station in thirty minutes had a tremendous price tag attached to it, and the local actors hope to get as much financial support as possible from the nation state.

One essential question about the new growth regime and the complicated partnerships is who plays the role of coordinator in the scalar tension? The shift from the nation state to the multi-scalar growth regime means that the nature of leadership has changed, coordination becoming an essential role in need of a leader. However, the role of coordination has not yet clearly manifested itself. There are not many examples of conflict coordination, but a rare one is in the construction of the Incheon Bridge. ${ }^{25}$ The nation state (The Ministry of Land, Transport and Maritime Affairs) wanted to build a 700-meter long bridge. The local port business argued that to minimize economic harm to shipping companies, it should be 1000 meters long, which would make it so that ships would not have to make a detour, which they would were the bridge to be built at only 700 meters. This extended length would increase the price tag an extra 100 million won and extend the construction period an additional year. Ultimately, a compromise between the nation state and the residents was reached for an 800meter bridge. The nation state and the city government split the extra cost 50/50. At that time, different ministries had different points of view on the matter. The Ministry of Transportation wanted to build the bridge as soon as possible. The Ministry of Maritime Affairs and Fisheries, (MOMAF) supported the extension of the bridge, while the Ministry of the Knowledge Economy did not want to spend more money. In this case, the prime minister's office made the coordination efforts.

The national assembly played the role of informal coordinator, interviewees said. If a conflict arose between the central and the local actors, the local actors would depend on the national assembly, to which they sent briefings. Although it did not play a significant role, it was able to initiate laws. Local actors (the Free Economic Zone and the city government) as well as the nation state depended substantially on the assembly to change and maintain present laws. The assembly could conduct an investigation of the government. To avoid having to investigate, departments of the nation state would try to respond to assembly members.

\section{Conclusion}

The Songdo New City development has witnessed a new form of growth regime that embraces partnership among multi-scalar actors. It has also showed the interface between the new politics of urban development and the path dependent dominance of the state in the South Korean context. Our findings demonstrate, first, that an increasing number of actors from various scales have become involved over time and have begun to form a new instrumental growth regime for project realization. This new growth regime has resulted from the downward rescaling of the former initiative of the nation state to the local scale, followed by a subsequent upward rescaling to the national scale again. In addition to the nation state and the city government, the Incheon Free Economic Zone Authority, international developers, the national assembly, domestic developers, and civic organizations became involved. As well, the state attempted to make the Incheon Free Economic Zone Authority a Special Purpose City government. Although this approach failed, it indicated the state's

\footnotetext{
25 The Incheon Bridge, opening in October 2009, provides direct access between Songdo and Incheon International Airport. It is the longest-spanning cable-stayed bridge in South Korea. The sea-crossing bridge section was funded by the private sector. Korea Expressway Corporation and the national government's Ministry of Land, Transport, and Maritime Affairs managed the project.
} 
interest in regaining dominance and highlighted the tensions that exist between the state and the city government.

Our findings on this particular type of growth regime propose the following theoretical considerations. First, the formation of a growth regime is contextualized in a particular spatio-temporal logic in which statehood is rescaled to local and global scales. The multi-scalar growth regime in the case of Songdo belongs to the category of instrumental regime that pursues a target project, short-term and growth-oriented. An essential factor to constitute such a regime is the entrepreneurialism of the local government. The entrepreneurialism in our case comes partly from the tradition of the developmental state, which was downward rescaled to the local scale.

Second, reconsidering the boundaries of a regime is critical in looking at contemporary growth politics through growth regime theory. Expanding the boundaries of city governance beyond governmental actors was one of the critical contributions of regime theory. The concept of the multi-scalar growth regime questions who is in and who is out in terms of the roles in exchange politics and influence. Forming a multi-scalar growth regime has entailed rearranging previous networks that accompanied conflicts based on different interests and different scales. The boundaries issue also helps to specify relevant actors within a regime. The boundaries question redefines the notion of governing. The formation of a growth regime in collaboration with multiple sectors at multiple levels of scale influences the dominance and leadership style of the government.

Regime theory has focused on exchange politics and cooperation in the interests of common goals. This was an effect, mainly, of the fact that stable networks based on the longterm development contract and cooperation in the interests of urban growth were something new. However, elaborating the cooperation process often reveals that the boundary of different interests and the cooperation that they effect within a regime develops and evolves. A growth regime bears tension between interests held in common between different actors and conflicting interests from the start. The conflict aspect is an essential part of the cooperative conflict process (Sen, 1990, 1999), during which power relations matter and membership in a regime becomes clear.

Regime theory has focused on exchange politics and cooperation in the interests of common goals. This was an effect, mainly, of the newness of their stable networks based on the long-term development contract and cooperation in the interests of urban growth. However, elaborating the cooperation process often reveals that the boundary of different interests and the cooperation that they effect within a regime develops and evolves. A growth regime, from the start, bears tension between interests held in common between different actors and conflicting interests. The conflict aspect is an essential part of the cooperative conflict process (Sen, 1990, 1999), during which power relations matter and membership in a regime becomes clear. 


\section{References}

Abidin, Kusno. 2015 Forthcoming. City of Power and Pain: A Story of Jakarta. International Journal of Urban Sciences. Vol. 19(1)

Allen J, Cochrane A, 2007, "Beyond the territorial fix: regional assemblages, politics and power" Regional Studies 41 1161-1175

Allison G T, Halperin M H, 1972, "Bureaucratic politics: a paradigm and some policy implications" World Politics 24 40-79

Asia Economy Newspaper [Asia Kyungje] 2011, "Olhae 'yeoksekwon' bunyang apart, Jeonkuk 3man 6000gagu", 8 February, http://www.asiae.co.kr/news/view.htm?idxno=2011020809164933553

Asia Kyungje 2010, "Hankukpan 'Las Vegas' 2014 nyeon mun yeonda", 10 February, http://www.asiae.co.kr/news/view.htm?idxno=2010021011554024840

Bae Y, Sellers J M, 2007, "Globalization, the developmental state and the politics of urban growth in Korea: a multilevel analysis" International Journal of Urban and Regional Research 31 543-560

Bayirbağ M K, 2010, "Local entrepreneurialism and state rescaling in Turkey" Urban studies 47 363-385

Bendor J, Moe T, 1985, "An adaptive model of bureaucratic politics" The American Political Science Review 79(3) 755-774

Bernstein M, 1955 Regulating Business by Independent Commission (Princeton University Press, Princeton)

Blanco I, 2013, "Analysing urban governance networks: bringing regime theory back "

Environment and Planning C: Government and Policy 31 276-291

Brenner N, 2004 New State Spaces: Urban Regime and the Rescaling of Statehood (Oxford University Press, Oxford)

Brenner N, 2009, "Open questions on state rescaling" Cambridge Journal of Regions, Economy and Society 2 123-139

Bulkeley H, 2005, "Reconfiguring environmental governance: towards a politics of scales and networks" Political geography 24 875-902

Carpenter D, 2010, "Institutional strangulation: bureaucratic politics and financial reform in the Obama administration" Perspectives on Politics 8 825-846

Cater D, 1964 Power in Washington (Vintage, New York)

Chang D-O, 2003 Demystifying the developmental state: a critique of the theories and practices of the state in the development of capital relations in Korea $\mathrm{PhD}$ thesis, University of Warwick

Chu C-W, 2000, "The evaluation of the Five-year Two Million Housing Unit Construction Plan (1988-92)", in Planning for a Better Urban Living Environment in Asia Eds A Yeh and M K Ng (Aldershot Burlington, Ashgate) pp 172-187

Chung J-Y, Kirby R J R, 2002 The Political Economy of Development and Environment in Korea (Routledge, London)

Cox K R, Mair A, 1991, "From Localised Social Structures to Localities as Agents" Environment and Planning A 23 197-213

Cox K, Wood A, 1997, "Competition and cooperation in mediating the global: the case of local economic development. " Competition and Change 2 65-94

Davies J S, 2003, "Partnerships versus regimes: Why regime theory cannot explain urban coalitions in the UK" Journal of Urban Affairs 25 253-269

Delaney D, Leitner H, 1997, "The political construction of scale" Political geography 16 9398 
Dong-A Newspaper [Dong-A Ilbo], 2010, "(Miraeul Seongjanggiji 'Kyungjejayu guyeok' )

$<7>$ Incheon hyunjusowa koyaje", 06 April,

http://news.donga.com/3/all/20100406/27371724/1

Dong-A Newspaper 2005, "(Incheon/Gyeong-gi) Incheon University Song-do ijeon

kyehwoek pyoryu", 5 July, http://news.donga.com/3/all/20050705/8206688/1

Freeman J L, 1965 The Political Process (Random House, New York)

Fujita, Kuniko, 2015 Forthcoming, "The landscape of Tokyo power". International Journal of Urban Sciences. 19 (1)

Gais T L, Peterson M A, Walker J L, 1984, "Interest groups, iron triangles and representative institutions in American national government" British Journal of Political Science 14 161185

Goodwin M, Jones M, Jones R, 2005, "Devolution, constitutional change and economic development: explaining and understanding the new institutional geographies of the British state" Regional Studies 39 421-436

Granovetter M, 1985, "Economic action and social structure: the problem of embeddedness" American journal of sociology 91 481-510

Hahm S D, Plein L C, 1995, "Institutions and technological development in Korea: The role of the presidency" Comparative Politics 28 55-76

Hangyere Newspaper 2006, "Kyeongje jayuguyeok, tkbyuljachijero jeonhwan ganeong", 23 July, http://www.hani.co.kr/arti/economy/economy_general/143572.html

Harding A, 1994, "Urban regimes and growth machines: toward a cross national research agenda" Urban Affairs Quarterly 29 356-383

Harvey D, 1989, "From Managerialism to Entrepreneurialism: The Transformation in Urban Governance in Late Capitalism" Geografiska Annaler. Series B, Human Geography 71 3-17 Harvey D, 2005 A Brief History of Neoliberalism. (Oxford University Press, New York) Imbroscio D L, 2003, "Overcoming the neglect of economics in urban regime theory" Journal of Urban Affairs 25 271-284

Incheon City Government and Ministries of Knowledge Economy, 2007, "The Global City Incheon Free Economic Zone"

Incheon Civil Measure Committee, 2003, "The problems of the Free Economic Zones and Alternatives", Incheon Citizens' Forum

Incheon Free Economic Zone Authority, 2010 Incheon Free Economic Zone Journal Incheon Free Economic Zone Authority, 2010, "The Seven Regulations to Resolve to activate the development and attract investment of the Incheon Free Economic Zone" Incheon Free Economic Zone Journal

Incheon Free Economic Zone, 2009, "A suggestion to remove the application of the price controls on new apartments and the advanced sale system to Free Economic Zones", An internal report submitted to the National Assembly

Jessop B, 1990 State Theory: Putting the Capitalist State in Its Place (Polity Press, Cambridge)

Jessop B, 1994, "Post-Fordism and the state", in Post-Fordism: A reader Eds A Amin (Blackwell, Oxford) pp 251-279

Jessop B, 2002 The Future of the Capitalist State (Polity Press, Cambridge)

Jessop B, 2009, "Changing spatialities of the state and their implications for state power", in The 5th East Asian Regional Conference in Alternative Geography Eds Korea Association of Space and Environment Research, Seoul, Korea

Johnson C, 1982 Miti and the Japanese Miracle: The Growth of Industry: 1925-1975

(Stanford University Press, Stanford, California) 
Jonas A E G, Ward K, 2007, "Introduction to a debate on city-regions: New geographies of regime, democracy and social reproduction" International Journal of Urban and Regional Research 31 169-178

Jones M, 2001, "The rise of the regional state in economic governance: partnerships for prosperity or new scales of state power?" Environment and Planning A 33 (7) 1185-1212 Jones M, Goodwin M, Jones R, 2005, "State modernization, devolution and economic governance: an introduction and guide to debate" Regional Studies 39 397-403 Jung Ang Newspaper [Jung Ang Ilbo] 2011, "Hasukwansaup robi hyumui Posco kunseol apsu susaek" 19 May, http://live.joinsmsn.com/news/article/article.asp?total_id=5509178\&ctg=1200\&tm= Jung Ang Newspaper [Jung Ang Ilbo], 2011, "Suntaekgwa Jibjung sijakdoln kyeongjejayuguyeok, 'Chungrajigu' utneonda", 26 January, http://article.joinsmsn.com/news/article/article.asp?total_id=4979699\&cloc=olink\%7Carticle \%7Cdefault

Kevin R. Cox, Spaces of dependence, spaces of engagement and the politics of scale, or : looking for local politics, Political Geography, Volume 17, Issue 1, January 1998, Pages 1-23 Kim C-H, Kim K-H, 2000, "The political economy of Korean government policies on real estate" Urban studies 37 1157-1169

Kim J W, Ahn Y-J, 2006, "Background and dynamics of free economic zones in Korea" Journal of the Korean Urban Geographical Society 9 79-87

Kim K, 2006, Free Economic Zones in Korea (Korea Institute for Industrial Economics \& Trade, Seoul)

Kim S H, Ahn H H, 2002, "The peculiar "publicness" of housing in South Korea", in Seeking Shelter on the Pacific Rim: Financial globalization, Social Change, and the Housing Market Eds G A Dymski and D Isenberg (Armonk, NY, London) pp 211-231

Kim W B, 1999, "National competitiveness and governance of Seoul, Korea", in Urban and Regional Governance in the Asia Pacific Eds J Friedmann (Institute of Asian Research, University of British Columbia).

Kong T Y, 2000 Politics of Economic Reform in South Korea: A Fragile Miracle (Routledge, London)

Kwon O H, 2007, "Comparative Analysis of Korean and Chinese Special Economic Zone" Local Government Research 10 284-302

La Grange A, HN Jung, The commodification of land and housing: the case of South Korea, Volume 19, Issue 4, 2004

Laffont J-J, Tirole J, 1991, "The politics of government decision-making: A theory of regulatory capture" The Quarterly Journal of Economics 106 1089-1127

Laquian A A, 2005, Beyond Metropolis: The Planning and Governance of Asia's MegaUrban Regions (The Johns Hopkins University Press, Baltimore)

Lee S-C, 2005, "The development of free economic zone project in Korea: The case of Incheon Free Economic Zone" DongHyangGwa JeonMang 48-64

Lee Y S, Shin H R, 2012, "Negotiating the polycentric city region: developmental state politics of new town development in the Seoul capital region" Urban Studies 49 1333-1355 Levine M E, Forrence J L, 1990, "Regulatory capture, public interest, and the public agenda: Toward a synthesis" Journal of Law Economics \& Organization 6 167-198 Logan J, Molotch H L, 1987 Urban Fortunes: the Political Economy of Place (University of California Press, Berkeley, CA)

MacLeod G, 2001, "Beyond soft institutionalism: accumulation, regulation, and their geographical fixes" Environment and Planning A 33 1145-1167 
MacLeod G, Goodwin M, 1999, "Space, scale and state strategy: rethinking urban and regional regime. " Progress in Human Geography 23 503-527

MacLeod G, Jones M, 1999, "Reregulating a regional rustbelt: Institutional fixes, entrepreneurial discourse, and the politics of representation. " Environment and Planning D: Society and Space 17 575-605

MacLeod G, Jones M, 2007, "Territorial, scalar, networked, connected: In what sense a 'regional world'? " Regional Studies 41 1177-1191

Marston S, 2000, "The social construction of scale" Progress in Human Geography 24219 242

McConnell G, 1966 Private Power and American Democracy (Knopf, New York)

McCool D, 1990, "Subgovernments as determinants of political viability" Political Science Quarterly 105 269-293

Minns J, 2001, "Of miracles and models: the rise and decline of the developmental state in South Korea" Third World Quarterly 22 1025-1043

Molotch H, 1976, "The city as a growth machine: toward a political economy of place"

American journal of sociology 82 309-332

Moon C-I, Prasad R, 1994, "Beyond the developmental state: networks, politics, institutions" Governance 7 360-386

Mossberger K, Stoker G, 2001, "The evolution of urban regime theory the challenge of conceptualization" Urban Affairs Review 36 810-834

Niskanen W A, 1974, "Bureaucracy", in Democracy and Public Choice Ed C K Rowley (Basil Blackwell, Oxford) pp 130-140

Onis Z, 1991, "The logic of the developmental state" Comparative Politics 24 109-126

Park B G, 1998, "Where do tigers sleep at night? The state's role in housing policy in South Korea and Singapore" Economic Geography 74 272-288

Park B G, 2003, "Territorialized party politics and the politics of local economic development: State-led industrialization and political regionalism in South Korea" Political Geography 22 811-839.

Park B G, 2008, "Uneven development, inter-scalar tensions, and the politics of decentralization in South Korea" International Journal of Urban and Regional Research 32 40-59

Park Y S, 2008 A Man Who Changed the Map of Korea. (Hangook Kyeongje Shinmun, Seoul)

Peck J, Tickell J, 1992, "Local modes of social regulation? Regulation theory, Thatcherism and uneven development. " Geoforum 23 347-363

Pempel T J, 1999, "The developmental regime in a changing world economy", in The Developmental State Eds M Woo-Cummings (Cornell University Press, The Developmental State) pp 137-181

Peterson P, 1981 City Limits (The University of Chicago Press, Chicago)

Powell W W, 1990, "Neither market nor hierarchy: Network forms of organization", in Research in Organizational Behavior Eds M S Barry, L L Cummings (JAI Press, Oxford) pp 295-336

Reed M G, Bruyneel S, 2010, "Rescaling environmental regime, rethinking the state: A threedimensional review" Progress in Human Geography 34 646-653

Saito A, 2003, "Global city formation in a capitalist developmental state: Tokyo and the waterfront sub-centre project" Urban studies 40 283-308

Sen A, 1990, Gender and cooperative conflicts, in: I. Tinker (Ed.) Persistent Inequalities:

Women and World Development (New York, Oxford University Press).

Sen A, 1999 Development as Freedom (New York, Anchor Books). 
Silver J J, 2009, "Weighing in on scale: synthesizing disciplinary approaches to scale in the context of building interdisciplinary resource management" Society and Natural Resources 21 921-929

Smith N, 1992, "Contours of a spatialized politics: homeless vehicles and the production of geographical scale" Social Text 33 54-81

Sonn, J.W. 2007, "Insulation with solidarity as a political condition for implementation of polarized development strategy: the South Korean experience and its theoretical implications." International Planning Studies 12221 - 240

Sonn, J.W. 2010 "Contesting state rescaling: An analysis of the South Korean state's discursive strategy against devolution" Antipode 42 1200-1224

Stigler G, 1971, "The theory of economic regulation" Bell Journal of Economics and Management Science 2 3-21

Stoker G, Mossberger K, 1994, "Urban regime theory in comparative perspective"

Environment and Planning C: Government and Policy 12 195-212

Stone C N, 1989 Regime Politics (University Press of Kansas, Lawrence)

Stone C N, 1993, "Urban regimes and the capacity to govern: A Political Economy Approach" Journal of Urban Affairs 15 1-28

Stone C N, 2004, "It's More than the Economy after All: Continuing the Debate about Urban Regimes" Journal of Urban Affairs 26 1-19

Stratmann T, Baur M, 2002, "Plurality rule, proportional representation, and the German Bundestag: How incentives to pork-barrel differ across electoral systems" American Journal of Political Science 46 506-514

Swyngedouw E, 1997, "Neither global nor local: 'Glocalization' and the politics of scale", in Spaces of globalization: Reasserting the Power of the Local Eds K Cox (Guilford, New York) pp 137-166

Tsukamoto T, 2012, "Why is Japan neoliberalizing? Rescaling of the Japanese developmental state and ideology of state-capital fixing" Journal of Urban Affairs 34(4) 395-418

Weber M, 1968, "The types of legitimate domination", in Economy and Society: An Outline of Interpreting Sociology Eds G Roth, C Wittich (Bedminster Press, New York) pp 212-301 Yun K S, 2007, "The analysis of industry structure and industrial network", (Incheon Development Research Institute) 
Table 1 Changes of regime over time

\begin{tabular}{|l|l|l|l|l|}
\hline & \multicolumn{1}{|c|}{$\mathbf{1 9 8 6 - 1 9 8 8}$} & \multicolumn{1}{|c|}{$\mathbf{1 9 8 9 - 2 0 0 1}$} & \multicolumn{1}{|c|}{$\mathbf{2 0 0 2}$} & \multicolumn{2}{|c|}{ 2003-2010 } \\
\hline Key actors & City government & $\begin{array}{l}\text { City } \\
\text { government, } \\
\text { nation state }\end{array}$ & $\begin{array}{l}\text { Nation state, city } \\
\text { government, } \\
\text { international } \\
\text { developer, } \\
\text { domestic } \\
\text { developer }\end{array}$ & $\begin{array}{l}\text { Nation state, } \\
\text { city } \\
\text { government, } \\
\text { international } \\
\text { developer, } \\
\text { domestic } \\
\text { developer, civic } \\
\text { organizations }\end{array}$ \\
\hline Scales & Local & Local, national & $\begin{array}{l}\text { National, local, } \\
\text { global }\end{array}$ & $\begin{array}{l}\text { National, local, } \\
\text { global }\end{array}$ \\
\hline
\end{tabular}


Table 2 Songdo Interviews

\begin{tabular}{|c|c|c|c|c|}
\hline $\begin{array}{l}\text { Intervie } \\
\text { wee } \\
\text { number }\end{array}$ & affiliation & Interview date & $\begin{array}{l}\text { Interview } \\
\text { place }\end{array}$ & Interviewer(s) \\
\hline 1 & Media & April 8, 2010 & Office & Shin \\
\hline 2 & $\begin{array}{c}\text { Governmental } \\
\text { Research Institute }\end{array}$ & April 12, 2010 & Office & Shin \\
\hline 3 & $\begin{array}{c}\text { Governmental } \\
\text { Research Institute }\end{array}$ & April 12, 2010 & Office & Shin \\
\hline 4 & Civil society & April 13, 2010 & Office & Park, Shin \\
\hline 5 & $\begin{array}{l}\text { The Incheon Free } \\
\text { Economic Zone } \\
\text { authority }\end{array}$ & April 13, 2010 & Office & Park, Shin \\
\hline 6 & $\begin{array}{c}\text { The Incheon Free } \\
\text { Economic Zone } \\
\text { authority }\end{array}$ & April 13, 2010 & Office & Park, Shin \\
\hline 7 & $\begin{array}{l}\text { The Incheon Free } \\
\text { Economic Zone } \\
\text { authority }\end{array}$ & April 13, 2010 & Office & Park, Shin \\
\hline 8 & $\begin{array}{l}\text { The Incheon Free } \\
\text { Economic Zone } \\
\text { authority (former) }\end{array}$ & April 15, 2010 & Office & Sonn, Shin \\
\hline 9 & $\begin{array}{l}\text { The Incheon Free } \\
\text { Economic Zone } \\
\text { authority (former) }\end{array}$ & April 15, 2010 & Office & Shin \\
\hline 10 & $\begin{array}{l}\text { The Free Economic } \\
\text { Zone Planning Office }\end{array}$ & April 23, 2010 & Office & Shin \\
\hline 11 & $\begin{array}{c}\text { Governmental } \\
\text { Research Institute }\end{array}$ & April 19, 2010 & Office & Sonn \\
\hline
\end{tabular}




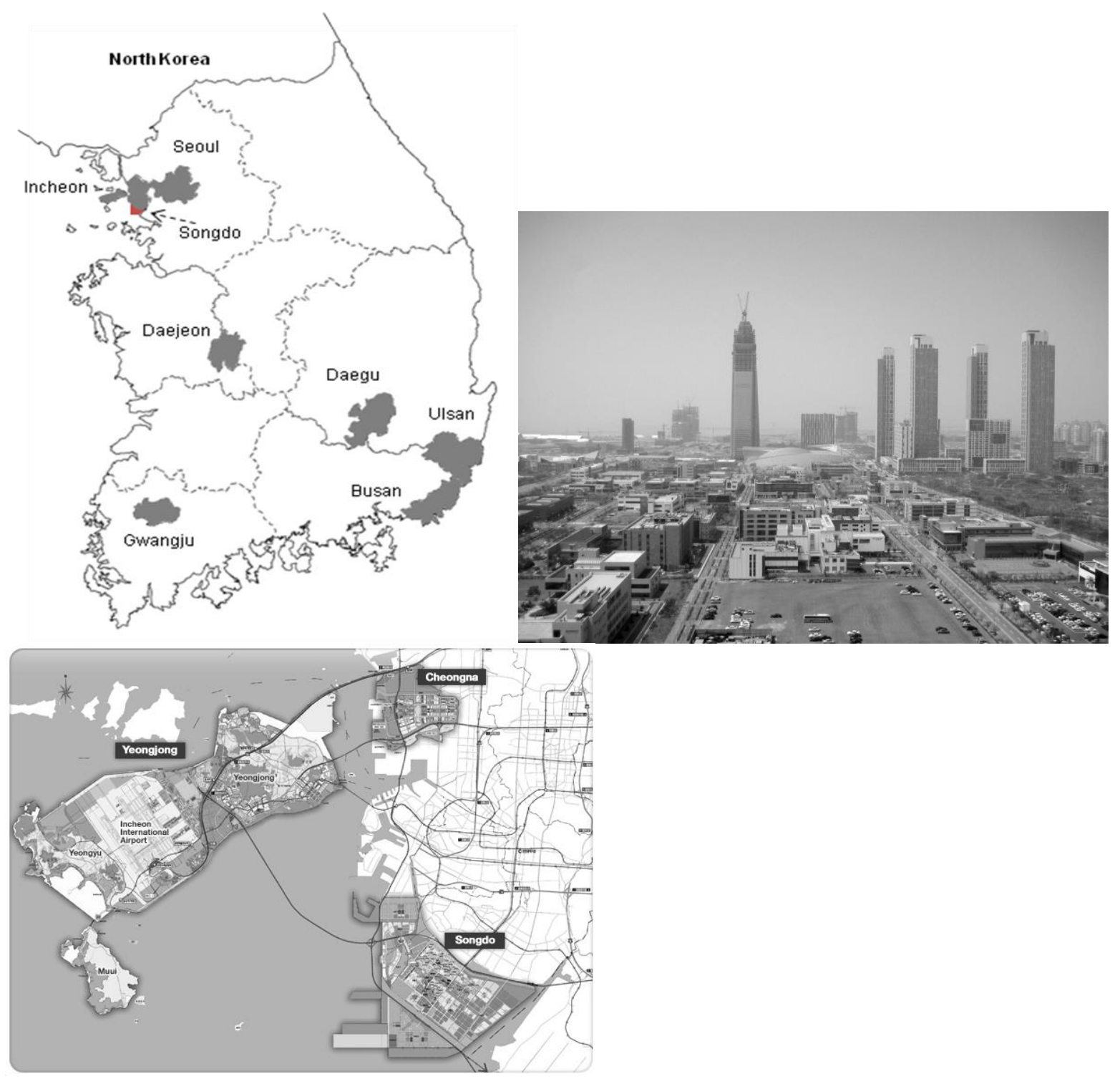

<Fig. 1> The Location of Songdo and a View of Songdo International City and developmental plan for Incheon Free Economic Zone

Source: www.Incheon Free Economic Zone.go.kr 


\section{Appendix 1: Timeline}

1985: Local bureaucrats persuaded the Mayor of Inchon for the reclamation of the land for the development of a Northeast Asian Business Hub for Songdo.

1987: The Business Hub plan was reported to the president with no effect.

1987: The presidential candidate Roh Taewoo's election manifest included two important built environment projects that would influence the Songdo project: 1) the construction plans for two million houses and 2) a plan for the Inchon International Airport.

1988: The Roh Taewoo Administration was inaugurated.

1988: Local bureaucrats changed the title of the Songdo development to Songdo New City in an effort to emphasize the housing element of the project.

1992: The Inchon Government completed the Songdo district development plan.

1996: The Media Valley Project was rejected by the Inchon Local Assembly.

1997: The East Asian economic crisis hit South Korea.

2001: The Inchon International Airport was completed.

2001: The Inchon Government exchanged MOU with Gale \& Wentworth Company .

2002: President Kim Daejoong announced his support for the Songdo project as a free economic zone and promised the provision of the physical infrastructure.

2002: Media started to criticize the Incheon Government for increasing the housing element of the Songdo project.

2002: The Roh Moo-Hyun Administration was inaugurated. The new administration announced its vision for a Northeast Asian Economic Hub Nation. Under this vision, the administration supported the idea of a free economic zone in Songdo.

2004: Songdo and two districts near Songdo were designated as Inchon Free Economic Zones, along with the other five areas across the country. 